largest of the chain of islands which runs from the south coast of Japan to the east coast of Formosa, and which include the Loochooan archiptlago. The island has never before been visited by a European, and presents many features of scientific and general interest. Dr. Döderlein spent sixteen days there, during six of which he was kept indoors and in darkness by a violent typhoon, which is described in the twenty-third number of the Transactions of the same Society by Mr. Knipping of Tokio. Two distinct types of people were found in the island, one pure Japanese, the other-probably the original inhabitants before the Japanese conquest-are about the same size as Japanese, but somewhat better built. The face is not so broad, and grows smaller towards the bottom, so that the chin is pointed, a feature rarely found in the Japanese, whose chins are broad and round. The lips and nose are thin, the bridge of the latter being convex. The eyes are large like those of the people of Southern Europe. The most striking portion of the appearance of this people, however, is the thick hair which they have all over their bodies. In this respect they closely resemble the Ainos of Yezo and Saghalin. The language, of which some examples are given, is evidently a dialect of Japanese, half-way between the latter and Loochooan. The customs are in many respects different from those of Japan. The women tatoo them. selves on the backs of the hands (the Airo women, it will be remembered, tatoo the lips) from the wrists to the roots of the nails. The marks are always the same, but no explanation of the custom could be given hy the people. When a girl reaches the age of thirteen the operation is performed on her hands by people specially trained for the purpose. Married women never blacken the teeth, as in Japan. Although the population is about $50, \infty 00$, there is neither priest nor temple in the island, and the people know nothing of a deity to whom they should pray. They pay a scrt of veneration to their ancestors, but only to individuals, not to the progenitors of their race or tribe, as in Japan. Life wonld run very smoothly with the people, were it not for a poisonous snake, called $h a b u$, belonging to the Trimeresurus class. It attains a length of six or seven feet, and is equal in venom to the most poisonous snakes. The Japanese fear to land on the island on account of these reptiles, which are found everywhere. They are said to pursue eels in the streams, to climb trees easily, and even to do so for the purpose of attacking travellers more easily. At night no one will stir abroad, for the bite is invariably fatal unless assistance is immediately procured. In one place a village of thirty-one houses was abandoned because the habu were numerous in the neighbourhood. The only cure employed is excision of the part, or even of the limb, which has been bitten. The general conclusion at which Dr. Döderlein arrives is that Osbima belongs in its fawna to the Loochoos, and has but little connection in this respect with Japan. He thinks, therefore, that the koundary between two great zoological regions, the paleoarctic and the oriental, lies between the island and Japan.

In the last number of the Proceedings of the Berlin Geographical Society Dr. G. Fritsch has an extremely suggestive paper on geography and anthropology as mulual helpmates. The writer dwells upon the great aid each of these studies might derive from the sister science, if conducted in a broad and enlightened spirit. There are problems connected with the evolution of man and with his present distribution over the earth's surface, the solution of which depends upon a more exact knowledge of the former distribution of land and water, especially in the Tertiary period. The gap that separates man from any of the living anthropoids is profound; but it may possibly be bridged over or contracted to smaller proporticns by the future discovery of fossil reniains in the tropical regions, where the race most probably originated. Should these regions fail ultimately to yield the connecting links, then the crnclusion would be strengthened that the evolution of mankind took place in some now submerged land, as, for instance, in the Lemuria of the Indian Ocean, or in the vast continent of which the Pacific islands may be regarded as the fragmentary remains. In the latter case the problem would remain practically insoluble, and the descent of men from some now extinct anthropoid forms would have to be regarded as at most an assumption incapable of strict demonstration. The present distribution of mankind, the writer goes on to point out, is largely bound up with more partial modifications of the earth's surface. A good instance is the Dravidian or aboriginal race of the Deccan, differentiated from the other types of the Asiatic mainland during the period that Southern India was still a triangular insular mass, before the now connecting Northern plains were created by the alluvia of the Indus and Ganges. From considerations of this sort Dr. Fritsch suggests a scheme of fundamental human types differing in some respects from any hitherto proposed by anthropologists, and insists especially on the necessity of separating the Koi.Koin (Hottentots and Bushmen) from the Negro proper. He also argues on similar grounds for the unity of the "home Americanns," whom he refuses to regard as a mere branch of the Mongol or any other type of the Old World.

IN a letter from Landana Père Carrie announces the arrival of Père Augouard's Stanley Pool expedition at Isangila on July 12. They were to resume their march for Manyanga on July I4, and hoped to reach it in eight days. Mr. Stanley is said to be hurrying on with his work in view of the expiry of his engagement with the International Association in March next.

THE chance of obtaining news of the missing Feannette exploring expedition before the winter closes in appears to be getting very remote. The revenue cutter Thomas Corwin has returned to San Francisco, and the steamer Alliance to Halifax, N.S., ithout any intelligence whatever of the party, and now we hear that the visit of the Rodgers to Wrangel Land has also been without result. Small boats belonging to the Rodgers circumnavigated Wrangel Land. The party in the toats also surveyed different parts of the island. The views from the top of the mountain on Wrangel Land disclosed sea all around it. The season had been most favourable for the purposes of exploration, owing to the openness of the navigation. The Rodjers would probably take up her winter quarters at St. Lawrence Bay, whence she expected to sail in June next, and proceed as far north as possible. Lieut. Berry finds that Wrangel Land is an island sixty miles in length.

THE November number of Petermann's Mittheilungen is mostly occupied with two papers-On the Water-ways of France, by H. Keller; and on the Marsh Region of the Equatorial Nile System and its Grass Barriers. The latter is a paper of great value and interest, giving the results of the writer's observations during his recent terrible Nile journey. It is accompanied by a map of part of the Bahr el Abiad and Babr el Seraf. There is also in the number a summary of the proceedings of the recent Venice Congress.

Tre Geographical Society at Bremen has received a telegram from the Brothers Krause, dated the 6 th inst., announcing iheir safe arrival at San Francisco with good scientific and ethnographic collections. These exploress had visited the Chukchi Peninsula at various points, and intended spending the winter in the north of Alaska.

\section{SCIENCE IN NEW SOUTH WALES}

A GOODLV record of scientific work is furnished from time to time by our vigorous colonies on the Australian continent, where (as in other young countries), if the aids to science are not so complete as in some parts of Europe, the incitements to philosophical observation of natural phenomena are, for obvious reasons, peculiarly strong.

The Fournal and Proceedings of the Royal Society of New South Wales for 1880 , recently received by us, includes, with other matter, many valuable observations adding to a knowledge of the country. We gather that within the last quarter of a century, from natural decay, ring-barking, and clearing for cultivation, at least one balf of the timbered land of the colony (it is estimated) has been denuded of trees. A very considerable diminution of rainfall might perhaps have been exfected in consequence, but this has certainly not been the case; indeed statistics rather indicate the reverse. The principal rivers, too, have not been diminished in volume of water. Instructive in this connection is the experience of $\mathrm{Mr}$. Abbott, with ring barking of trees on his run at Glengarry. This operation (for improvement of grazing capacity) be carried out in 1869 and 1870 , on most of the watershed of three creeks, each about two miles long, draining well-defined valleys shut in by high ridges of basalt. For twenty yerrs previously these creeks were dry watercourses, only holding water for a few days after rain, and in a few places in winter. But soon after ring-larking they became, and have continued, permanent streams, with increased flow of water and number of springs. The explanation Mr. Abloolt offers is that the large proportion of the rainfall formerly taken up by the gum-trees and evarorated, now finds its way to the creeks ane rivers. 
The reconds of thunder and hailstorms in New South Wales up to the end of 1878 were examined by Mr. H. C. Rus ell, with reference to the risk from hail to the Exhibition Building crected in 1879 . The list is given in this volume. Mr. Russell could not trace any period in thosc stoms, except that they scemed more numerou; in the first ycar after a drousht. They are not severe or numerous in wet years. The great number of siorws when the earth is paising through the November meteor strean is noted.

The so.called salt.huche; of Australia are known to have properties that are of great advantage to sheep, which relish and fatten on the food, especially in times of drought. Mr. Ilixon has analysed some eight of those fodders of the Riverina district, and shows, by comparion with well-known European fodders, that they stand well as to nutritive value. One is struck with the extraordinary amount of anh. In seven of the cight, the average ratios of total ash, prtaib, and common salt to digestible matter (oil, carbshydrates, and albuminoids), taken as 100 , are $47,9.538$ and 7.689 respectively; and the difference here from European fodders is conspicuous. Cotton bush (the ei yhth examined) ranks with the latter. Only two contain a very large proportion of common salt, viz. oldman salt bush (the most prized by graziers), has 15.403 , in the relation ju-t specifed, and suall salt bu $\mathrm{b}, 14590$. While digestion is doubtless promoted by the soluble chlorides, it is in the wool that the greatest effect of the diet (so rich i:s potash) might be expected, and the high esteem in which Riverina wool is held, is a verification of this.

Various hinds of coal of New South Wales have been sub jected to analysis by Mr. l)ixon and by Prof. Liversidge, the latter of whom specially wished to see how they compared with our coals. He found the Nortbern District coals to contain least ash, average percentage $4^{\circ} 6 \mathrm{I}$; those of the Western District bave 10:44 per cent.; and those of the Southern ro'99. Thus some of the Northern coal is quite equal in this respect to the Welsh and Scotch coals, and but little inferior to the English Newcastle coal. The quantity of sulphur in New South Wales coal is by no means excesive. Prof. Liversidge also furnishes an account of some minerals from New Caledonia, including the nickel-bearing Noumeaite. This mineral seems to be cum. pietely amorphous; the mass s lits up into smooth concave-convex pieces like petals of an unopened bud. It is in some cases soft and brittle, and in others hard and tough enough to be cut into ormaments. The colour varies from the palest tinge of green to full rich malachite green. The composition ranges from practically pure hydrated silizate of marmesia to what is also practically only hydrated silicate of nickel. The earthy cobalt ore (asbolite) from New Caledonia differi considerably from those met with in other plices; bargta is entirely absent, but magnesia seers to have taken its place in some case:

An interesting paper by Dr. Manning, medical superintendent of the Hospital of the Insane at Gladesville, treats of the causes of insanity in 3077 paticnts admitted to that institution in ten years from 1869; a comparison bcing alio drawn with English statistics. W' note that $3^{\circ} 9$ per ceut. of the cases of insanity are attributed to isolation ant nostalyia conjointly (a category not given in the English table). The cases of pure nostalgin were those of foreigners, who spoke English most imperfectly. The ca:es of isolation included shepherd:, whose occupation sone years ago was most lonely, and still $i$, in some places, though the state of things is improving in this respect. Dr. Manning found last year that more than one half (1038 out of 2036) of the inmates of those institution: in the colony were apparentiy quite friendless, and that ro per cent. were foreigners. The isolation, which is something terrible to a new e vi-ramt, and which lis's ofte' for years, is kept up by the disparity of the sexes, which at the cl sse of 1879 stood at 409,665 males and 324,617 females, and it is fostered by the peculiar shifting and re-tiess life of the miners and the bushmen. Dr. Manning thinks the insanity from intemperance bas been exaggerated; the percentage at Gladesville $i ; 8^{\circ} 3$. The vile quality of the drink (he considers) and the system of driaking (short reckless outbursts, with p-olonged periods of abstinence), are prominent factors in the result. Sunstroke, as might be supposed, causes insanity to a much greater ertent in New South Wale; than in Fngland; 5 per cent. of the cases are accredited to it. Dr. Manning also expresses the opinion that insanity through lactation prolonger beyond the ordinary time is more frequent. Again, he is struck with the number of cases admitted with symptoms of dyspepsia and "chronie inl health, "and he attributes a considerable number of those to the want of varied and properly cooked meals. As to hereditary transmission of insanity, the Gladesville statistics give only 7.2 per cent., but they are wuch le is complete than the English, owing to the difficulty of getting to know the family history.

We call do no more than briefly indicate some of the other subjects dealt with in thi; volume; sone new double stars, the longitude of Sydney Observatury, the opposition and magni. tudes of Uranus and Jupiter, the orlit clements of Comet l. 1880 , changes in the surface of Jupiter, catalogue of plants c.)llected by Furrest in North-West Australia, fossil fiora of Eastern Australia and Tasmania, pituric, iron acted on by sea water, wood inclosed in basalt, fossils from Palrozoic rocks of New South IVales, schemes of water supply for Sydney, wells in the Liverpool plains.

\section{ON THE APPLICATION OF PHOTOMETRY IN THE STUDY OF THE PHENOMENA OF DIFFUSION IN LIQUIDS}

§ I. SINCE the prublication in 1803 of Berthollet's work, ${ }^{1}$ in which it is already ascerted that the diffusion of salt soluti in: in water takes place according to the same laws as the proparation of heat in solids, an exact method has frequently been sought for deternining the coefficient of diffusion. The attempts in this direction have failed to give concurdant results, which may best be judged from a compilation of the numbers expressible in absolute units with reference to chloride of sodium, whose coefficient of diffusion in watcr has most frequently been measured. The coefficient is statcd to be-

$$
\begin{aligned}
& \text { By Graham, at } 5^{\circ} \mathrm{C} \text {. } \quad \ldots \quad \ldots \quad \ldots \quad 88
\end{aligned}
$$

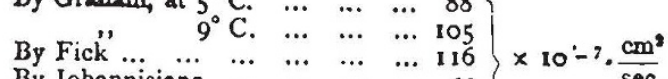

$$
\begin{aligned}
& \left.\begin{array}{lllllr}
\text { By Johannisjanz } & \ldots & \ldots & \ldots & \ldots & 116 \\
\text { By } & \ldots & \ldots & \ldots 3
\end{array}\right\} \times 10-7 \cdot \frac{\mathrm{sec}}{\mathrm{se}} \\
& \text { By Schuhmeister, at } 10^{\circ} \mathrm{C} . \ldots .
\end{aligned}
$$

When we inquire into the laws which govern this coefficient we mect with even greater discrepancie;. Thus Graham, Fick, and Schubmeister's researches indicate the increase of the co. efficient with the rive of temperature. Jobannisjanz finds $n$ ? such relationship. Thas $H$. F. Weber, experimenting with sulphate of zinc, coneludes that the coefficient of diffusion de creases with increase of concentration. Schnhmeister asser:s exactly the contrary.

The importance which diffusion has gaincd of late as a means of investigating and solving many proble ns connected with molecular physics ${ }^{2}$ indaced me to search for a method which should permit me to investigate the proce:ses of diffusion, $n n$ alone with more accuracy than heretisfore in that direction in which the final re:ults may be ascertained by simple weighing, but al in to open up a new field of research which has been inac. cessible up to now for want of suitable methods. A detailed descriotion of my method, and a full accoint of all the circum stabee: to be olserved in carrying out the experime.ts, will be found in Wiedemann's Anmalen, vol. xiii. pi. 606-23. I will only give here the gencral outlines.

In the middle of a large glass trough a glass dish is inverted. On the top of this dish a narrow but thicli glass rod is placed horizontally, and upon this four cylindrical ressels of approxi. mately equal beirht at suitable distances from cach other and from the walls of the trough. Theie are filled with solutions of the salt to be investigated, in such a way that the menis sus attains its maximum height. Water is now poured into the trough till it reaches in height $0.1 \mathrm{~cm}$. below the edge of the sbortest cylinder, and the whole allowed to stand for several hours to equalise the temperature. After this, by means of a specially constructed funnel, more water of exactly the same temperature as the water in the trough is introluced, until it reaches a height of several millimetres absve the $c d$, $c$ of the cylinders.

The apparatu; is now left to itself.

To internupt the experiment a method has been devise 1 , the description of which will also be found in Wiedemann's Anralen.

The rcsult is calculated by the formula-

$$
D=\frac{\pi}{4}\left(\mathrm{I}-\frac{c_{2}}{c_{1}}\right)^{2} \cdot \frac{1}{6},
$$

- Berthollet, "Essai de statique chimique," Paris, r8s3. "v.l. i., Pp. 409-429. 2 See Wroblewski, "On the Nature of the Absorption of Gases," in NATURE, vol. $x \times i$. p. 100. 